\title{
Lay Participation in Taiwan: Observations from Mock Trials
}

\author{
Mong-Hwa CHIN* \\ National Chiao Tung University School of Law, Taiwan
}

\begin{abstract}
This article introduces the designs and the potential problems of the new lay judge system in Taiwan. This article first describes the background of the development of lay participation in Taiwan, and the 2012 Observer Jury System and the 2018 Lay Judge System drafted by the judiciary. The core of this paper is a qualitative study of four mock trials conducted by four district courts in Taiwan. Through observations and interviews with mock trial lay judges, this article addresses three main problems of the new system, including professional judges' domination in deliberations, the comprehensibility of law, and lack of evidence rules. It also provides a discussion of the possible solutions to the problems observed. This article urges that training sessions should be provided to both lay judges and legal professionals, adjust the discovery rule, provide guidance on sentencing, and create evidentiary rules.
\end{abstract}

Keywords: lay participation, lay judge, deliberation, sentencing, evidentiary rules, Taiwan

\section{INTRODUCTION}

This article addresses issues relating to Taiwan's new lay participation system. Taiwan has been trying to adopt a lay participation system for more than two decades. In 1994, the Judicial Yuan, the highest judicial administrative authority in Taiwan, introduced the first lay participation system proposal. The 1994 project was part of broader political reform. At the time, Taiwan had just ended the White Terror era and lifted martial law. The people in Taiwan were finally given the right of a popular vote in the presidential elections. Once considered as serving the authoritarian regime, the judicial system now hopes to serve the people. The proposed system would allow certain criminal cases to be presided over by three professional judges and two lay participants-meaning that cases would be decided by a majority of five votes. ${ }^{1}$

The proposal failed, however, mainly because it was difficult to accommodate the practice of criminal trials at that time because they were mostly conducted on paper. Judges relied on

* Associate Professor at National Chiao Tung University School of Law, Taiwan. The author would like to thank the editors and reviewers of the Asian Journal of Law and Society, and Professor Hiroshi Fukurai for their valuable comments. The author is also very grateful to the administrators, judges, and lay judges who allowed him to observe and record these mock trials. Correspondence to Mong-Hwa Chin, National Chiao Tung University School of Law, 1001 University Road, Hsinchu, Taiwan. E-mail address: mhchin@nctu.edu.tw.

1. Sun (2013), p. 68. 
the exchange of legal documents to make decisions. Compared to strengthening and reviewing the dossier, the trial itself played a much more insignificant role. It was a time when prosecutors sometimes did not appear in the courtrooms because they believed the indictment document sufficiently covered everything. Even when prosecutors did appear in the courtrooms, it was not uncommon for them to only read out the indictment. ${ }^{2}$ Because there was no real courtroom activity, asking both attorneys to present their cases live in court would create a huge burden for both parties. Judges did not favour the new system either because it would almost certainly increase their time spent in the courtrooms. It should also be mentioned that the proposal did allow lay participants to read the dossier, just like professional judges. However, it was generally believed that this would too heavily burden lay participants. The 1994 proposal was never presented to the legislature because of these doubts.

The Judicial Yuan introduced a new lay participation proposal in 2012 to regain the trust of the people after a series of cases provoked public dissatisfaction toward the judicial system. One of the controversial cases was a 2010 child sexual abuse case; the victim was a six-year-old girl, and the prosecutor charged the defendant with aggravated rape and requested that the court sentence him to seven years and ten months in prison. A district court found that there was no evidence showing that the defendant had penetrated the victim against the victim's will. Therefore, the defendant was convicted of statutory rape and sentenced to three years and two months in prison. ${ }^{3}$ In the same year, the Taiwan Supreme Court vacated and remanded a guilty verdict that involved sex abuse of a three-year-old girl. The court applied a similar rationale and reasoned that there was no sign that the defendant's conduct had been against the victim's will. Upon remand, the Taiwan High Court delivered a not-guilty verdict. ${ }^{4}$ These two cases resulted in an uproar in society. The media branded the judges as "dinosaurs" or "fossils," meaning that their opinions were outdated and incompatible with the views of the community. ${ }^{5}$

In addition to these incidents, the lay participation movement in Taiwan could also be seen as part of a larger resurgence of lay adjudicatory systems in East Asia. ${ }^{6}$ The design process of Taiwan's lay participation system was profoundly influenced by two neighbour countries: Japan and South Korea. Japan introduced "saiban-in seido" in 2009 and South Korea's jury was launched in 2008. Not unlike Taiwan, the decision to adopt the Japanese saiban-in seido and the Korean jury models seem to be bottom-up. The Justice System Reform Council (JSRC) initially suggested the saiban-in seido model to address the problems of wrongful conviction and violation of criminal defendants' rights ${ }^{7}$; the Korean jury system was built on the dissatisfaction and distrust toward the traditional, single-minded judges and is meant to address the public's needs for high-quality judicial service. The primary purpose of Korea's jury system was to increase the democratic legitimacy of the judicial process and enhance the transparency and credibility of the judiciary. ${ }^{8}$ It is also worth mentioning that, in addition to

\footnotetext{
2. Jrf (1998).

3. Taiwan Kaohsiung District Court 99 Suzi No. 422 Criminal Decision.

4. Taiwan Supreme Court 99 Taishangzi No. 4894 Criminal Decision.

5. Taiwantoday (2012).

6. Fukurai, Chan, \& Miyazawa (2010), pp. iv-v.

7. Fukurai (2013), p. 521.

8. Ibid., pp. 180-1; Fukurai (2007), pp. 321-2.
} 
Japan and South Korea, even China introduced a new directive in 2004 to improve the existing People's Assessor system. The directive was designed to tackle issues of corruption, favouritism, and influence, and to improve the judicial decision-making process. Therefore, differently from Japan and South Korea, the People's Assessor system applies not only in criminal trials, but also in civil and administrative trials. ${ }^{9}$ With three of the most important players in East Asia moving toward adopting or strengthening lay participation, it seems only natural for Taiwan to follow this trend.

Although Japan and South Korea adopted lay participation systems roughly at the same time, there are many essential differences between the two systems. First, Japan's system is a quasi-jury panel of six lay judges and three professional judges. ${ }^{10}$ A Korean jury, on the other hand, consists of five to nine jurors, depending on the seriousness of the case. ${ }^{11}$ Second, while the Japanese system is a mixed tribunal that encourages judges to interact with saibanin, the Korean model provides an opportunity for the jury to deliberate alone without the participation of judges. Judges may join in the discussion only when requested by the majority of jurors or when the jurors could not reach a unanimous verdict. ${ }^{12}$ Third, the Japanese system does not allow the defendant to choose whether to be tried by the quasi-jury, but the Korean system enables the defendant to turn down a jury trial, and the court may also decide not to conduct a jury trial under certain circumstances such as when jurors or their families or relatives face possible danger. ${ }^{13}$

Using lay participation to promote the overall trustworthiness of the judiciary is not without precedents. Japan, for example, surveyed people in 2009 about their experience serving as lay judges. The survey collected over 5,000 responses. The result showed an overwhelming (96.7\%) positive experience from people who served as lay judges. Similar positive results were also found in another lay participation entity in Japan, "Kensatsu Shinsa Kai" (the Committees for the Inquest of Prosecution (CIP)). The CIP is a committee that reviews prosecutor's non-indictment decisions. It was reported that, by participating in CIP, people generally had a positive experience, which helped them to realize that their service was pivotal to maintaining a fair criminal justice system. ${ }^{14}$ Another study that compared the Japanese CIP members with American jurors also found that the experience of serving in the CIP or as a juror generated greater willingness to serve in these positions again and even greater support for the legal system. ${ }^{15}$ Similar outcomes were also observed in Korea, where surveys showed that 96-99\% of jurors were satisfied with their experience in court and had a positive feeling toward the jury system. ${ }^{16}$ The successful experiences of Japan and Korea played a crucial role in Taiwan's decision to move toward a lay participation system.

9. Landsman \& Zhang (2008), p. 206.

10. Fukurai, supra note 8, p. 322.

11. Lee (2009), pp. 186, 188.

12. Hans (2017), pp. 488-9.

13. Fukurai, supra note 8, p. 322; Lee, supra note 11, p. 184.

14. Ibusuki (2010), pp. 44-6.

15. Fukurai, supra note 8, p. 317.

16. Park (2010), p. 577. However, there was also strong evidence showing that jurors' positive experience did not transfer to the judicial system as a whole. In a 2014 survey of 1,100 Koreans, only $30 \%$ responded that they had confidence toward the judicial system. See Kwon (2016), p. 124. 
In designing the new system, Taiwan's judiciary and the legislature had very different views toward lay participation. As the following discussion will illustrate, when lay participation was first proposed in 2012, it tried to combine the characteristics of the systems adopted in both Japan and Korea. The 2012 proposal essentially followed the Japanese saiban-in model, but the lay judges' opinions remained only advisory, which is a characteristic of the Korean model. The proposal failed because the legislature thought the democratic function of lay participation was not incorporated into the Bill. Eventually, the 2018 proposal fully embraced the saiban-in model and gave lay judges the status to vote with professional judges as equals during deliberation.

Overall, the Taiwan government generally agreed that it was necessary to adopt some form of lay participation system to address the legitimacy and trust issues of the judiciary. Therefore, although the law has not yet been passed, the Judicial Yuan has already started to conduct lay judge mock trials in the district courts in early 2018. This article will first provide a brief literature review on mixed tribunals. The third part will introduce the 2012 proposal, then the 2018 proposal that is primarily based on the 2012 version. Then, this paper will examine the mock trials conducted by Judicial Yuan and discuss the issues observed by the author in four of these mock trials. Finally, this paper will attempt to provide solutions to these issues.

\section{LESSONS LEARNED FROM OTHER COUNTRIES}

There are three distinct models of lay participation in the world. One is the American jury model, which typically requires 12 jurors to form unanimous decisions on guilt and then requires professional judges to decide on the sentence. During a trial, professional judges play the role of an umpire. They control the information presented to the jury and make sure that a fair trial is conducted.

The second model is the lay magistrate judge model found in England and Wales. Magistrate judges are citizen volunteers who do not require legal training or qualifications. They are selected by advisory committees based on qualities such as good character, sound judgment, and social awareness. Once appointed, they will typically sit in a panel of three magistrate judges, assisted by a qualified legal adviser, and preside over criminal or family cases. However, they do not handle the most serious crimes such as murder, robbery, or rape, as these crimes are reserved to the Crown Court. ${ }^{17}$

The last model is the mixed-tribunal model adopted by civil-law countries such as Germany. In a mixed tribunal, judges and lay assessors decide cases together on both the guilt and sentencing. The idea is that through discussion, lay judges may have more faith in professional judges, who can benefit from the lay judges' life experience. While the American jury model seems to have earned greater fame, when deciding to adopt a lay participation model, most civil-law countries tend to choose the conservative option of a mixed tribunal, mainly because the judiciary is often hesitant to entrust the power of fact-finding entirely to laymen. ${ }^{18}$

17. Judiciary (2018).

18. Park, supra note 16, p. 532. 
However, the problem of mixed tribunals is apparent. Much of the criticism regarding the joint decision-making process between judges and laypersons concerns the possibility that judges will dominate the process and diminish the importance of the lay participants. For example, a 1972 study on German mixed tribunals estimated that lay judges have affected only $1.4 \%$ of all the cases they heard. ${ }^{19}$ More recent studies have reported that most lay judges in Poland, Hungary, and Croatia did not actively or meaningfully participate during the trial process. It has also been said that, in Croatia, Sweden, and Germany, lay judges rarely express opinions that differ from those of professional judges. In rare cases when they disagree, it is usually lay judges who changed their votes. It is believed that the contribution of lay judges in these countries is generally considered minor. ${ }^{20}$ The same problem was also observed in Venezuela, where scholars believed that unanimous results in mixed tribunals occurred because of the professional judge's influence. ${ }^{21}$

Despite the adverse effects, there is evidence showing that, in mixed tribunals, judges' involvement may help lay judges make decisions. In South Korea, for example, a study shows that judges enhanced the jury's understanding of the law and helped prevent them from making mistakes, such as using evidence related to sentencing to determine guilt. ${ }^{22}$ Therefore, although judges may have the potential to affect lay judges adversely, they may also provide assistance. It appears that a professional judge who welcomes input from lay judges, while also refraining from expressing his or her opinion, is critical to a successful mixed tribunal. ${ }^{23}$

In addition to relying on a professional judges' performance, one must also consider other alternatives for mitigating the problem of professional judges dominating the process. One critical approach is to educate both lawyers and the public about the new procedure and to increase the comprehensibility of that procedure and law. When Croatian judges were asked about the problems of lay judges during deliberation, most judges believed that the biggest challenge for lay judges was their "lack of legal knowledge or their lack of understanding of legal norms." 24 The Japanese government understood that to facilitate meaningful participation, it is vital for the government to make efforts to narrow the gap regarding legal knowledge between saiban-in and professional judges. There is an ongoing effort to help professional judges to communicate with lay judges. Both the prosecutor's office and the bar association also hold training events to help prosecutors and defence attorneys understand the new procedure and how to address the lay judges. ${ }^{25}$

Unlike lay judges in Germany or China, who serve for a term after appointment and may preside over multiple cases, Japanese saiban-ins are selected on a case-by-case basis. Once a case is over, the saiban-ins are dismissed and another new group of laymen will be selected for another case. This design aims to decrease the likelihood of saiban-ins being affected by the existing judicial culture, judicial bureaucracy, and ranks, and thus decrease overall judicial influence on laymen. However, the price is that every saiban-in is new to the judicial

\footnotetext{
19. Ibid., p. 541.

20. Ivkonic (2007), pp. 440-1.

21. Hendler (2008), p. 8.

22. Lee \& Woo (2016), p. 194.

23. Hans (2008), p. 289.

24. Ivkonic, supra note 20, p. 441.

25. Wilson (2017a), p. 112.
} 
system. It becomes even more critical for saiban-ins to have basic knowledge of the system and procedure. To address this issue, resources were also used to educate the public about the new system. Before the first trial, the Japanese government and other organizations spent more than US\$50 million on advertisements, symposiums, and mock trials to promote the new system and to educate the public. ${ }^{26}$

The importance of effective communication cannot be overemphasized. Before the implementation of the saiban-in seido model, it was pointed out that oral advocacy skills and effective communication would be vital to the success of the new system, and that both lawyers should receive training to develop the necessary skills. ${ }^{27}$ The prosecutor's office foresaw the importance and the difficulties of performative skills and courtroom proficiency. They held systematic training programmes to help prosecutors learn how to use technology and communicate effectively to lay judges in the courtroom. Defence lawyers, on the other hand, did not have the same amount of time or resources to receive the same training. It was reported that such differences in preparation reflected directly on courtroom performance. A survey showed that more than $80 \%$ of lay judges felt that prosecutors' presentations were easy to understand, but less than half of the lay judges felt the same for defence' presentations. $^{28}$

Another issue is the comprehensibility of the legal language. A Japanese forensic language expert reported that, while the Japanese saiban-in seido seemed to operate smoothly without causing major failures, a survey conducted by the Japanese Supreme Court showed that more and more people who served as lay judges had difficulties in understanding the language used in the courtrooms. For example, mock trials in Japan showed that lay judges do not understand the difference between "murder through wilful negligence" and "recklessness." The presiding judge had to translate the concepts into something perceivable by lay judges. ${ }^{29}$ Therefore, efforts should be made to reconstruct the legal language so that it can be more comprehensible to lay judges.

To summarize, past literature indicates that, in mixed tribunals, it is highly likely that professional judges will dominate the joint deliberation process and thus undermine the intended goal of the entire system. To mitigate this issue, Japan focused on providing education to judges, prosecutors, defence attorneys, and the public. Many scholars have thus far described Japan's system as a success. ${ }^{30}$ Japan's experience shows that a successful lay participation system should accommodate lay judges by making the appearance and presentation of law more comprehensible and enhancing legal professionals' ability to effectively communicate with lay judges.

\section{THE 2012 PROPOSAL: THE OBSERVER JURY SYSTEM}

The 2012 proposal was called "Guan Shen Zhi” (the "observer jury" system). The legislature note about Article 1 of the proposed Bill stated that lack of communication and interaction

\footnotetext{
26. Ibid., p. 101.

27. Wilson (2017b), p. 869.

28. Ibusuki, supra note 14 , p. 46.

29. Okawara (2012), p. 46.

30. Wilson, supra note 25 , p. 108.
} 
between the judicial system and public opinion was the key reason why the public distrusted judges. Therefore, the proposed system was designed mainly to promote interaction and understanding between laypersons and the judiciary.

\subsection{Pre-Trial Process}

Because the primary purpose of the observer jury system was to earn the trust of the public, the accused did not have the right to choose between trials conducted by professional judges or mixed panels. In the words of the designers, Taiwan's Code of Criminal Procedure was already diverting different crimes to different courts. Easier cases were fast-tracked and harder cases received a full trial. Therefore,

if a case has the potential of promoting the public's trust and improving the trial, then there is nothing wrong if the accused is not able to refuse being tried by a mixed panel of observer jury and professional judges. ${ }^{31}$

According to the Bill, a judge can exclude the case from being tried by an observer jury only under certain circumstances, such as when the court reasonably believed that trial observers would be biased, when a case was too complicated for a layperson to understand, or when the defendant had confessed. ${ }^{32}$

The observer jury trial had jurisdiction over crimes punishable by death, life imprisonment, or any other crime specified by the Judicial Yuan, except for drug-related crimes or cases of juvenile delinquency. ${ }^{33}$ The Bill excluded these two kinds of cases because the designers believed that lay participants are less likely to meaningfully contribute in drugrelated cases and that special juvenile courts should resolve juvenile delinquency cases.

To promote efficiency and to ensure the procedure produced correct results, the courts would appoint counsel for every defendant in an observer jury trial if the defendant had not already hired one. ${ }^{34}$ It is worth emphasizing that the defendant cannot choose to defend himself without counsel. That is, unlike American juries, pro se representation is not an option for the defendant. Counsel representation was considered both right and obligatory in observer jury trials.

The presiding judge would appoint a commissioned judge to conduct pre-trial preparatory proceedings to ensure that the observer jury understood the case. In these proceedings, the judge and the parties should determine the scope of the facts, the charges, and whether the defendant will enter a guilty plea. They should also determine the key factual and legal issues of the case and decide the sequence, scope, and methodology of the investigation to produce a list of evidence that will be used in the trial and to order an expert witness or schedule an inspection. Most importantly, if the parties argued against the admissibility of a piece of evidence, the commissioned judge should bring the issue back to the three-judge panel to decide whether the evidence at issue can be presented to the observer jury. At the end of pretrial proceedings, the commissioned judge must produce a detailed trial plan. ${ }^{35}$

\footnotetext{
31. Judicial Yuan (2011), p. 207.

32. Bill of Observer Jury Pilot Program (2012), Art. 6.

33. Ibid., Art. 5.

34. Ibid., Art. 5.

35. Ibid., Art. 39.
} 


\subsection{Voir Dire}

The proposed Bill provided that an observer jury should consist of a party of five lay observers. ${ }^{36}$ Members of the observer jury should be selected randomly from nationals at least 23 years old who have lived in the jurisdiction continually for four months. ${ }^{37}$ A procedure similar to the American voir dire process was designed to qualify these candidates, who could be excluded due to a prior criminal conviction, incompetency, or relationship with the parties involved. ${ }^{38}$ Potential candidates may also be exempted due to age (older than 70), illness, prior experience of serving on the jury, or if serving on the jury conflicted with other important duties at work or home. ${ }^{39}$ People who have an expertise in law, such as lawyers or law professors, however, were not eligible to serve on the jury. ${ }^{40}$ Because the goal of the system was to create a platform for laypersons to interact with legal professionals, selecting members of the legal professional community as jury members would defeat this purpose. In addition to challenges with cause, each party had three peremptory challenges. ${ }^{41}$ Finally, five people should be randomly selected from qualified candidates. ${ }^{42}$ Three professional judges would then join these five people.

The Bill of the observer jury attempted to change the fundamental culture of using dossiers in criminal trials. The Code of Criminal Procedure Article 264 provides that "[w]hen a prosecution is initiated, the record and exhibits shall be sent therewith to the court." The records and exhibit together are called the "dossier." Once the prosecutor decides to indict the accused, the dossier is transferred to the court. After that, the defence attorney may review the dossier and prepare to file their written defence. The biggest problem of using a dossier in criminal trials is that judges will be exposed to the information gathered by the prosecutor before trial and thus have a bias against the defendant. In addition to the problem of bias, reading the dossier before trial would give professional judges a significant advantage in understanding the case. It was believed that this could potentially exacerbate the inherent problem of mixed courts: professional judges dominating the discussion process. As a result, the observer jury Bill provided that judges and observer juries alike were not allowed to read the dossier before trial, and they could only access the indictment. ${ }^{43}$

\subsection{During Trial}

The trial would begin immediately after voir dire. Jurors would first be sworn in and then judges would provide several things: a concise explanation of the procedure, the powers and obligations of the jury, the general principals of criminal law and procedure, the crime involved in this case, the factual and legal disputes of the case, the scope of evidence presented, and the estimated time that the parties would spend on their presentation. ${ }^{44}$ Before

\footnotetext{
36. Ibid., Art. 3.

37. Ibid., Arts 12, 17.

38. Ibid., Arts 26, 27.

39. Ibid., Art. 16.

40. Ibid., Art. 14.

41. Ibid., Art. 27.

42. Ibid., Art. 28.

43. Ibid., Art. 45.

44. Ibid., Art. 47.
} 
the presentation of evidence, the two parties were required to make opening statements, which should consist of the facts, the evidence that would be presented, and the relationship between facts and the evidence. ${ }^{45}$ After the cross-examination of a witness, observer jurors could request the presiding judge to raise questions on his or her behalf. With the permission of the presiding judge, observer jurors could also question the witness directly. ${ }^{46}$ To promote the interaction between professional judges and observer jurors, the presiding judge could hold intermediate discussions during the trial to discuss the case, including anything from the facts and evidence to the law. The observer juror could state their own opinion or raise questions with professional judges. ${ }^{47}$ After all evidence was presented in the court, the final stage was oral argument. ${ }^{48}$

\subsection{Deliberation}

The system allowed the observer jury to discuss their decision with professional judges during final deliberation. However, as the name of the programme indicated, the observer jury was only allowed to participate in a trial, deliberate on both guilt and sentence, and express its opinion, but the observer jury did not have the actual power to decide cases. Professional judges were required to consider the majority opinion of the observer jury, but it did not bind them. Professional judges retained the power to decide cases independently. ${ }^{49}$ If the majority of professional judges determined that the defendant was guilty, the panel would then proceed to discuss the sentencing. ${ }^{50}$ Similarly, in the sentencing phase, observer juries were only allowed to suggest advice for professional judges. If the majority opinion of professional judges contradicted the majority opinion of the observer jury, professional judges were required to explain in person and in the written verdict to illustrate why they disagreed with the majority opinion. ${ }^{51}$ It was believed that, although the majority opinion was not binding on judges, they would still respect the majority opinion because of their duty to explain.

Politically speaking, the problem of the observer jury system was obvious. Without the power to decide a case, the new jury system was criticized, as it reflected the judiciary's distrust of the people instead of trying to resolve people's distrust of the judiciary. It was also argued that the new system viewed the distrust of the judiciary as a misunderstanding between legal elites and laypersons. ${ }^{52}$ The Judicial Yuan seemed to assume that, once people entered the court and experienced the whole litigation process, they would regain faith in the judiciary. Thus, the people were wrong, not the judiciary. Eventually, the 2012 proposal did not manage to gather enough support in the legislature and the Bill was put on hold.

\footnotetext{
45. Ibid., Art. 51.

46. Ibid., Art. 52.

47. Ibid., Arts 47, 50, 54.

48. Ibid., Art. 53.

49. Ibid., Art. 59.

50. Ibid., Art. 56.

51. Ibid., Art. 64.

52. Zheng (2013), pp. 115-6.
} 


\section{THE 2018 PROPOSAL: THE LAY JUDGES SYSTEM}

In 2016, after the presidential election, a new president from the opposing party was elected. The government appointed new leadership for the Judicial Yuan. Based on the foundations established by the former observer jury system, the Judicial Yuan proposed a new lay participation system called the "lay judge system." The vast majority of the new Bill was the same as the observer jury system. However, unlike the observer jury, lay judges have substantially the same power as professional judges during a trial. The future lay participation trial will be decided by a panel consisting of nine people, including three professional judges and six lay judges. ${ }^{53}$ According to a recent poll conducted by the Judicial Yuan, the new deliberation procedures received overwhelming support from the public. Over $95 \%$ of the subjects of the poll supported a mixed tribunal that allowed lay judges and professional judges to make decisions together. ${ }^{54}$ A two-thirds majority (six votes) will decide guilty verdicts and the majority must have at least one vote from the three professional judges. If a two-thirds majority cannot be reached, the panel will have to deliver a not-guilty verdict. If a guilty verdict can be reached, the lay judges may also participate and vote in the sentencing phase. The sentence will be decided on a simple majority vote. If there is a divergence regarding the length of sentence, the majority opinion will be formed by adding the people who favour the least favourable opinion to the people with the next favourable opinions until the number of people reaches majority. ${ }^{55}$

In addition to the power mentioned above that is given to lay judges, there are two important differences between the two Bills. First, cases that are eligible for lay judge trial are no longer limited to crimes punishable by death or a life sentence, but expanded to include cases that are punishable by a statutory minimum of seven years or intentional crimes resulting in the death of a victim. ${ }^{56}$ Second, referring to the Japanese saiban-in system, the new Bill created a so-called "three-stage discovery procedure." The first stage is requesting prosecutors to provide evidence that is directly related to the indicted facts and a list of the remaining evidence. ${ }^{57}$ The second stage allows defence attorneys to apply for discovery based on the list of evidence. The defence must explain why the evidence may be important to impeach the evidence presented by the prosecutor and necessary to the defence's strategy. The defence should also specify the facts related to the applied evidence. ${ }^{58}$ The third stage allows the defence to apply for further discovery of the remaining evidence if it is necessary for the defence's case. ${ }^{59}$ The court will resolve disputes on discovery. The court may order prosecutors to disclose all evidence if necessary. ${ }^{60}$ The Judicial Yuan claims that the purpose of the new discovery system is to promote efficiency by limiting the amount of evidence presented in a trial. ${ }^{61}$

\footnotetext{
53. Bill of Lay Judges (2018), Art. 3.

54. You \& Yu (2018), p. 34.

55. Bill of Lay Judges, supra note 53, Art. 83.

56. Ibid., Art. 5.

57. Ibid., Arts 53, 54.

58. Ibid., Art. 55.

59. Ibid., Art. 59.

60. Ibid., Art. 61.

61. Zhang (2018).
} 


\section{THE MOCK TRIALS}

From the beginning of 2018, the Judicial Yuan requested that all district courts in Taiwan conduct mock trials. For the public, the purpose of conducting these mock trials was to promote the new system. For legal professionals, the mock trials provided a platform for practice and discussion. These mock trials were held in real courtrooms, real professional judges presided over the trial, and lay judges were chosen from the public through a voir dire process. The mock trials also used actual case files and invited local attorneys to serve as defence attorneys and prosecutors. Each mock trial lasted for two full days. The court would typically spend the morning of the first day on the voir dire process. The presentation of evidence would start from the afternoon of the first day to the early afternoon of the second day, when deliberation would ensue. Because the mock trials were for demonstration purposes only, the court would limit the number of the witnesses called and amount of evidence presented to ensure that the case would end on time.

From January to May 2018, the author of this paper attended four of these mock trials in four different district courts (Taipei District Court, Chiayi District Court, Shilin District Court, and Changhua District Court). During these mock trials, the audience was able to observe all trial proceedings, including intermediate discussion and deliberation. In addition to the lay judges, there was a shadow jury in each mock trial. The shadow juries sat in the courtroom and participated in the whole trial. However, they did not have the chance to ask questions to professional judges in intermediate discussions. Before deliberation in every mock trial, a judge was appointed to deliver instructions on the law and procedure to the shadow jury. Although shadow jurors were not allowed to interact with judges throughout the trial, they could ask questions regarding the law to a judge during deliberation. After giving instructions, the judge would leave and act as a standby outside the deliberation room in case there were questions. Besides legal questions, the shadow jury had to make their own decisions without the assistance of professional judges during deliberation. Unlike lay judges, shadow juries do not deliberate on sentencing. The purpose of creating a shadow jury was to observe the behaviour of lay judges when professional judges do not participate in the discussion or deliberation.

Table 1 illustrates the jurisdiction, facts, the crime charged, and key evidence of each case.

The following discussion is based on the direct observation of the mock trials and focusgroup interviews with lay judges after the trial. Until now, Taiwan has never adopted any form of lay participation. The criminal procedure has developed over decades without consideration for laypersons. The discussion will focus on the gap between the judiciary and the lay judges, and what happens when these two parallel worlds clash with each other.

\subsection{Professional Judges' Domination in Deliberations}

The Judicial Yuan and judges were generally aware of the problems of the European mixed courts in which lay judges were often influenced by professional judges. They decided to follow the Japanese model of using case-by-case lay judges, instead of the German tenure model, to prevent the judicial culture and ranks of professional judges from affecting lay judges. The Bill also specifically requested that, during deliberation, before professional judges speak, lay judges should have the opportunity to express their opinions first. ${ }^{62}$

62. Bill of Lay Judges, supra note 53, Art. 82. 
Table 1. Case information of mock trials

\begin{tabular}{|c|c|c|c|}
\hline Court & Facts and issue & Crime charged & Key evidence \\
\hline Taipei & $\begin{array}{l}\text { Facts: On } 1 \text { October 2017, the Defendant (D) attacked his wife after } \\
\text { realizing that she applied for a home loan without informing him. } \\
D \text { used his fist and a kitchen knife as weapons and caused the } \\
\text { victim (V) to suffer multiple injuries on her head, face, neck, and } \\
\text { right hand. D's daughter witnessed the event and called the police } \\
\text { for help when the attack occurred. At the time of the event, the V } \\
\text { had a protective order against D due to a previous occurrence of } \\
\text { domestic violence. } \\
\text { Issue: Whether the D acted with an intention to kill. }\end{array}$ & $\begin{array}{l}\text { 1. Attempted } \\
\text { murder } \\
\text { 2. Violation of } \\
\text { protective } \\
\text { order }\end{array}$ & $\begin{array}{l}\text { 1. Testimony of the } \mathrm{V} \\
\text { 2. Testimony of the } \\
\text { daughter } \\
\text { 3. Testimony of the } \mathrm{D} \\
\text { 4. The weapon } \\
\text { 5. Medical reports of } \\
\text { the V } \\
\text { 6. Picture of the crime } \\
\text { scene }\end{array}$ \\
\hline Chiayi & $\begin{array}{l}\text { Facts: On } 26 \text { May } 2017 \text {, after arguing with his mother, the D locked } \\
\text { himself inside his room and started a fire. He used a lighter to } \\
\text { ignite newspapers and magazines. His mother noticed the smoke } \\
\text { materializing from D's room and called the fire department on the } \\
\text { phone. She then opened the door and extinguished the flame. The } \\
\text { room was not on fire, but the table inside the room was damaged, } \\
\text { and there was a pile of papers on the floor. } \\
\text { Issue: Whether the D acted with an intention to commit arson. } \\
\text { Whether the fire was big enough to damage the house. Whether } \\
\text { the D tried to put out the fire. Whether the D had mental } \\
\text { disabilities. }\end{array}$ & Attempted arson & $\begin{array}{l}\text { 1. Testimony of the D } \\
\text { 2. Testimony of the } \\
\text { D's mother } \\
\text { 3. Photograph of the } \\
\text { crime scene } \\
\text { 4. Expert's testimony } \\
\text { on the cause of the } \\
\text { fire } \\
\text { 5. Psychiatry report of } \\
\text { the D }\end{array}$ \\
\hline Shilin & $\begin{array}{l}\text { Facts: On } 20 \text { July } 2015, \mathrm{D} \text { had an argument with his family and } \\
\text { stole a utility knife from the convenience store. He went to the } \\
\text { Shuanglian Metro station in Taipei and stabbed people randomly } \\
\text { while walking along the escalator, injuring four passengers. Two } \\
\text { of the victims had chest wounds. The third V had a wound on the } \\
\text { shoulder, and the fourth V had a wound on the back. The D later } \\
\text { surrendered himself in the metro station. } \\
\text { Issue: Whether the D acted with an intention to kill. }\end{array}$ & $\begin{array}{l}\text { Attempted } \\
\text { murder }\end{array}$ & $\begin{array}{l}\text { 1. The weapon } \\
\text { 2. Security camera } \\
\text { footage of the } \\
\text { stabbing } \\
\text { 3. Medical reports of } \\
\text { the Vs } \\
\text { 4. Psychiatry report of } \\
\text { the D } \\
\text { 5. Testimony of the } \\
\text { Vs } \\
\text { 6. Testimony of the D }\end{array}$ \\
\hline Changhua & $\begin{array}{l}\text { Facts: D had a suspicion that his wife and V had an affair. On } 12 \\
\text { August } 2017 \text {, D attacked V at a breakfast restaurant run by his } \\
\text { wife. He followed the V to the restroom and used a fruit knife to } \\
\text { stab the V's lower back twice and then ran away from the crime } \\
\text { scene. The V died before arriving at the hospital. D's wife and } \\
\text { another person were at the crime scene when it took place, but } \\
\text { they did not witness the event. D asked his niece to contact the } \\
\text { police about the case and turned himself in voluntarily on the } \\
\text { same day, but it was unclear whether D, by law, was eligible for a } \\
\text { reduced sentence. } \\
\text { Issue: Whether the D acted with an intention to kill. Whether the } \\
\text { D turned himself in and is eligible for a reduced sentence. }\end{array}$ & $\begin{array}{l}\text { 1. Murder } \\
\text { 2. Theft }\end{array}$ & $\begin{array}{l}\text { 1. Testimony of D's } \\
\text { wife } \\
\text { 2. Testimony of the } \\
\text { Medical examiner } \\
\text { 3. Testimony of D } \\
\text { 4. Testimony of the } \\
\text { leading police officer } \\
\text { 5. Autopsy report } \\
\text { 6. Pictures of the crime } \\
\text { scene } \\
\text { 7. The weapon }\end{array}$ \\
\hline
\end{tabular}

Because this issue has been discussed extensively since 2012, when the observer jury system was first introduced, professional judges tried their best not to dominate the discussion in the mock trials.

Most of the judges in the mock trials performed flawlessly; nevertheless, in mock trials of Shilin and Chiayi, lay judges reported that professional judges tried to lead the discussion. Some lay judges claimed that professional judges were apparently trying to influence them. Another lay judge commented that every lay judge could tell that professional judges already had a preconceived decision during deliberation. Sometimes, even when judges did not intend to influence lay judges, they could still cause the same effect simply by expressing their own opinion. In Shilin, lay judges had different opinions on whether the defendant acted with an intent to kill or an intent to harm. They asked for the opinion of the presiding professional judge, but the discussion ended almost immediately after the professional judge expressed his opinion. A lay judge reported that, whenever professional judges raised a question, he felt the questions were more like a quiz and he tended not to answer because he 
feared he might be incorrect. ${ }^{63}$ From what was observed from the interaction between professional judges and lay judges, it seemed essential for professional judges to learn of the impracticality of lay judges treating them as equals in the deliberation room due to the professional judges' social status, expertise in law, and experience with handling cases. To prevent ending the discussion prematurely, professional judges should be aware that lay judges are vulnerable to judicial influence and insist on waiting until lay judges finish expressing their opinions before joining the discussion.

Compared to the guilt phase, lay judges experienced the most difficulty in making decisions in the sentencing phase. When the Judicial Yuan was designing the lay participation system, one of its goals was to respond to the criticism that professional judges were too lenient in sentencing. Thus, the new lay participation system allows lay judges to deliberate on not only guilt, but also sentencing. The designers presumed that, with the input of lay judges, sentencing would become more consistent with public opinion and eventually create more trust in the judicial system. However, in Chiayi and Shilin, lay judges expressed frustration at the sentencing deliberation during the interview. They were frustrated because they knew the importance of the sentencing procedure but were not given enough guidance, and they did not know the punishment level that was reasonable for a particular crime or comparable to past decisions. They also had difficulty understanding sentencing factors, such as the definition and effect of turning oneself into authorities. ${ }^{64}$ In Changhua, whether the defendant had turned himself in was a key issue during the sentencing deliberation. The law provides that "if a person voluntarily turns himself in for an offense not yet discovered, the punishment may be reduced." ${ }^{65}$ To receive a reduced punishment, the defendant must have actually turned himself or herself in and allowed law enforcement to learn his or her identity. However, for some reason, some of the lay judges thought that the intention of turning oneself in was the most important factor. The professional judges intervened to correct lay judges' wrong interpretation of the law but, at the same time, the judge revealed his judgment of whether that defendant had validly turned himself into authorities. Once the professional judge revealed his thoughts, the discussion stopped. Lay judges never had a chance to have a full discussion on the issue. ${ }^{66}$

The experience also indicated that the frustration lay judges experienced may develop into negative opinions regarding the new system. In Chiayi, two lay judges reported that their original decisions on sentencing were different from that of professional judges. However, since they did not have sufficient confidence in their own decisions, they changed their votes immediately after learning the decisions of the professional judges. Both appeared to be unsatisfied with the design of the new system. On the one hand, they seemed anxious about whether their decisions were appropriate and tried their best not to embarrass themselves; on the other, they seemed angry because they felt unhelpful and insignificant. ${ }^{67}$

63. Author's note on Taipei District Court Mock Trial 30-31 January 2018; author's note on Shilin District Court Mock Trial 8-9 February 2018.

64. Author's note on Changhua District Court Mock Trial 26-27 April 2018; author's note on Chiayi District Court Mock Trial 1-2 February 2018.

65. Code of Criminal Law (Taiwan), Art. 62.

66. Author's note on Changhua District Court Mock Trial 26-27 April 2018.

67. Ibid. 
The designer of the system assumed that lay judges wanted to participate in every stage of the trial, so the more power they received, the better the results. It appears that this is not always the case. In all four mock trials, lay judges suggested that lay participation should be limited only to the guilt phase, not to the sentencing phase. One of the lay judges elaborated that, if lay judges are required to make sentencing decisions, they should only be expected to make general recommendations, such as "harsher" or "more lenient." 68

Notably, when asked what should be improved, lay judges in all four mock trials suggested that professional judges should train them prior to sitting on the bench. They indicated that the training could take place either before coming to court or during the first day in court. They believe that pre-trial training would help them to perform better as judges. If the law continues to request lay judges to deliberate on sentencing, extensive training on sentencing may be necessary to ensure meaningful participation. In fact, pre-trial training is not unprecedented, and China, the Czech Republic, Poland, and Finland all provide training to lay judges before trial. ${ }^{69}$ On the other hand, none of the jurors in the shadow jury made similar suggestions. This indicates the lack of confidence of lay judges came from sentencing deliberations or their interactions with professional judges.

\subsection{The Comprehensibility of Law}

In the mock trials, after voir dire and before the trial begins, the presiding judge would spend an hour or so discussing the law with the chosen lay judges. The judges would use this very limited time to explain the trial procedure, authorities and obligations of lay judges, and basic principles of the criminal procedure, such as the presumption of innocence, the doctrine of free proof, that the prosecutor bears the burden of proof, and that proof is needed beyond a reasonable doubt. To lower the burden on lay judges, the presiding judge would even summarize the undisputed and disputed facts of the case and the relevant law. ${ }^{70}$

However, many lay judges still reported that they were having difficulty understanding the law itself and legal concepts. Among the 56 people who served as either a lay judge or a member of the shadow jury in these four mock trials, $35(62.5 \%)$ of them reported that it was difficult to understand the legal language, and 21 (37.5\%) of them reported that they did not experience difficulty. ${ }^{71}$

Sometimes, legal phrases that were straightforward to legal professionals troubled lay judges. For example, attorneys could raise "objections" to each other in the direct and crossexamination of witnesses. A lay judge reported during the interview that he did not understand the word "objection."72 This was probably because, unlike the word "objection," which is commonly used in English in everyday life, the equivalent Mandarin word, "yi-yi," is not. Another example that bothered lay judges is the concept of "chungzhifan" "73 or

68. Ibid.

69. Levin \& Tice (2009), p. 4.

70. Taipei District Court mock trial pre-trial instructions (2018).

71. These first-hand data are collected by the author through a survey conducted after the mock trials.

72. Author's note on Taipei District Court Mock Trial 30-31 January 2018.

73. Art. 26 of the Criminal Code: a conduct that is impossible to accomplish the intended offence and is not dangerous is not punishable. 
"bunengfan."74 In these cases, because the Chinese words do not reveal much about the meanings, it was extremely difficult for lay judges to understand them. ${ }^{75}$

The same problem also applies to some of the fundamental legal concepts mentioned above. For example, in English, laypersons generally do not have much difficulty understanding phrases such as "prosecutor bears the burden of proof" or "proof beyond reasonable doubt"; however, when foreign legal concepts are translated into Mandarin, they become somewhat strange and complicated. Legal professionals in Taiwan are familiar with these foreign terms because Japanese, German, and American laws deeply influence Taiwanese laws. It is not uncommon for Taiwanese lawyers to cite foreign legal authority in official legal documents. However, many of these legal terminologies that are translated from foreign languages are not used or heard in everyday life. Therefore, what is considered normal for legal professionals may complicate lay judges' understanding.

The shadow juries in these mock trials deliberated without the participation of judges unless judges were being called to answer legal questions. This provided a unique opportunity for us to observe the behaviours of the jury when judges were not involved. Throughout the deliberation process, there were many instances that indicated that the jury did not understand the importance of the legal principles set out in the jury instructions. For example, the instruction explicitly demanded the jury not to consider factors related to sentencing when determining guilt. However, there were still instances where jurors violated this instruction. In Shilin, when deciding whether the defendant committed attempted murder or simple assault, one of the jurors commented that it would be unreasonable to convict the defendant only for assault because the statutory sentence for assault is too low. Another juror pointed out that, considering the defendant's past experiences and educational background, it seemed unfair to ask him to take full responsibility. ${ }^{76}$ In Chiayi, when the jury was requested to choose between four crimes, a shadow juror commented that she supported whichever offence had the lighter sentence, without considering the elements of the crime. ${ }^{77}$ Also, shadow juries were not keen on asking questions to the judge; in four of the mock trials, judges were only summoned by the jury three times. This means lay judges are not always outspoken about uncertainties and questions.

However, it must be emphasized that lay judges' lack of knowledge of the law may also have merits. One of the lay judges from the shadow jury remarked that it did not make much sense for the attorneys to request lay judges to follow certain Supreme Court precedents. In the Taipei mock trial, the defendant was accused of injuring his wife with a knife. The key issue was determining the subjective intent of the defendant—whether he was trying to kill the victim (attempted murder) or just harming them (assault). Over the years, Taiwan's Supreme Court has developed a list of precedents to help courts distinguish attempted murder from assault, including the weapon used, injured body part, and seriousness of the injury. A lay judge argued that these kinds of Supreme Court precedents should not be

74. Art. 27, para. 1 of the Criminal Code: "If a conduct is performed in the commission of an offense and the actor voluntarily renounces the act or prevents it from producing its result, the punishment shall be reduced or remitted. This provision shall also apply to a case when the result does not occur but not due to the act of prevention by the actor so long as the actor has done his utmost to prevent it."

75. Author's note on Chiayi District Court Mock Trial 1-2 February 2018.

76. Author's note on Taipei District Court Mock Trial 30-31 January 2018.

77. Author's note on Chiayi District Court Mock Trial 1-2 February 2018. 
binding for lay judges because laypersons have full capacity to distinguish attempted murder from assault. The lay judge complained that emphasizing Supreme Court precedents was very misleading. Another lay judge stated that, if there were binding precedents, lay judges should also be informed of the facts upon which these precedents were based. From a legal perspective, the lay judge's comment encourages the designers to contemplate which precedents should be binding, which should not, and how these precedents are presented to lay judges. After all, lay judges should be given more room to determine facts.

Another issue related to the comprehensibility of law is the ability of lawyers to make oral presentations and arguments. For attorneys in Taiwan, giving an oral presentation and making an argument are, without a doubt, the most challenging features of the lay judge system. As mentioned earlier, the 1994 proposal failed because judges and attorneys were more familiar with resolving cases through the exchange of documents. Matters have improved in 2018, as practitioners now appreciate the importance of a face-to-face trial, but lay participation requires more than appreciation. It requires attorneys to possess the skillset to give persuasive oral presentations to laypersons.

If a person walks into a criminal trial in Taiwan, it would be difficult for that person to understand what the case is about just by listening to the oral exchanges in the courtroom. Practitioners seem to be more interested in resolving specific issues than providing a narrative of the case. This is because they have already established and communicated their narratives for the case through the exchange of written documents before the trial. By the time judges meet with attorneys face to face in court, the judges are already familiar with the arguments of both sides. The reason for meeting in court is to cross-examine witnesses and resolve any questions judges may have after reviewing the documents filed by both parties. Conversely, lay participation trials are different. While the parties may learn the opposite side's arguments through discovery, both professional and lay judges are forbidden from reading the dossier. This change requires attorneys to present their full case verbally in front of judges in the courtroom.

Decades of social science research have established that jurors understand and make sense of what is happening in court by organizing information into a chronological narrative. While jurors are absorbing information in trials, they are also making decisions about which pieces of evidence go well with the narrative and which pieces do not. If there is a gap in the story, jurors will fill it with their existing knowledge. ${ }^{78}$ Understanding how laypersons make decisions and learn the skills of telling persuasive narratives is the key to effective communication.

Without the opportunity to receive proper training, many of the attorneys who participated in these four mock trials were still using an evidence-focused approach instead of a narrativefocused approach in presenting their cases. Lacking complete narratives, lay judges had to frequently use common sense or existing knowledge to independently complete information gaps. Judging from the interaction between lay judges during deliberation, one could conclude that the lay judges were generally unsatisfied with the amount of information provided

78. Pennington \& Hastie (1993), pp. 192-6; Devine (2012), pp. 26-7; Vidmar \& Hans (2007), pp. 141-2; Levett \& Devine (2017), pp. 13-4. 
by the attorneys. For example, an event before a murder may not be particularly significant for legal professionals because it is not directly related to the elements of the crime; however, it may affect the completeness of the narrative because knowing the specifics of the event may help to determine the motive or even the intention of the accused. In Taipei, for example, because neither side provided information on what had happened before the crime occurred, the lay judges in the shadow jury decided independently that the accused and the victim must have had a quarrel, which gave the accused a motive to commit the crime. ${ }^{79}$ Similarly, in another instance in Shilin, lay judges in the shadow jury also raised questions about why key witnesses were not called to testify. This question was never addressed by either party. ${ }^{80}$ Remarkably, leaving gaps in the narrative does not indicate a mistake. The point is that the effects of leaving gaps must be considered carefully by attorneys. Some of the attorneys who participated in the mock trials clearly did not have enough awareness of this issue.

Another sign that indicated the lack of ability to give oral presentations and make arguments was that almost every attorney in the mock trials relied heavily on PowerPoint slides. In all of the four mock trials I attended, slides were used not only for opening and closing statements, but also for the examination of witnesses; that is, attorneys listed their questions on slides. Attorneys, especially prosecutors, also tended to feature excerpts of witnesses' prior statements on slides even when the witnesses were testifying in court. This indicates that prosecutors felt more comfortable presenting what they already had on file instead of cross-examining witnesses in court. The problem with using documents instead of live testimony is that, unlike legal professionals, lay judges are more susceptible to live witness testimony. In these four mock trials, the lay judges in the shadow jury almost never reviewed prior statements during deliberation, even when these statements were available to them. In fact, the lay judges in the shadow jury almost never reviewed any of the documents provided to them except for photographs - again highlighting the importance of giving good oral presentations.

Arguably, using slides would help lay judges to understand the evidence, facts, and arguments; however, the downside of using slides was also obvious: when slides were used, everyone stared at the screen and no one looked at the person testifying. The excessive use of slides confirms that attorneys were not sufficiently confident enough to persuade judges through an oral presentation alone. This problem is particularly alarming if one considers that the cases designed for mock trials are relatively straightforward ones with simple facts and fewer issues.

\subsection{Lack of Evidence Rules}

Another issue observed in the mock trials is a gap in the law itself. In the past, Americanstyle rules of evidence, which dictate how parties presented evidence in the courtroom, were not important in Taiwan because cases were not only decided from the exchange of legal documents, but also by professional judges alone. Rules that prevent fact-finders from being biased, misled, or confused were non-essential for criminal trials in Taiwan because the presumption was that professional judges were experienced and astute enough to avoid bias and confusion from information. However, similarly to the

79. Author's note on Changhua District Court Mock Trial 26-27 April 2018.

80. Author's note on Shilin District Court Mock Trial 8-9 February 2018. 
experience observed in Japan, with the participation of lay judges, presenting evidence orally and directly in the courtroom became essential to trials; these presumptions can no longer stand. ${ }^{81}$

One can observe the importance of creating evidence rules from the mock trials. In the trials of the attempted-murder and murder cases in Taipei, Changhua, and Shilin, the prosecutor used photographs to illustrate the injury of the victim or the crime scene. Because the mock trials used real case files, autopsy photographs of the deceased victim were also shown to the lay judges. It is undisputed that the parties should show fact-finders these photographs in attempted-murder and murder cases. The issue is the way in which these photographs were displayed in court. In the Changhua trial, prosecutors used enlarged, colour pictures multiple times to show the wound, autopsy, and bloody crime scene. The defence did not raise an objection to the presentation of these photographs, not because they were irresponsible, but because they were not effectively trained and no rules permitted them to object to the bloody photographs. $^{82}$

Similarly, in Changhua, prosecutors called the coroner as an expert witness. The coroner was an exceptionally fluent witness who not only provided her opinion on the cause of death, but developed a theory on how the incident occurred. To prove her theory, she invited the prosecutor to act as the victim and together they performed in court possible scenarios of the crime. Later, deliberations and interviews revealed that the simulation was extremely damaging to the defence's case. Many lay judges reported that the expert witness was very professional and eloquent. From a professional perspective, had there been a rule of evidence, the defence should have objected to the simulation for the reason that lay judges might be misled by over-evaluating the weight of such a performance. ${ }^{83}$

A third example is the prosecutor's use of high-publicity cases in Taiwan. In Shilin, the prosecutor referred to two other cases that involved random killings in his closing statement. The first case was the 2014 Cheng Chieh's case, which was the first ever stabbing spree that happened in the Taipei metro-with four people killed and 22 injured. The weapon was a 30cm-long fruit knife. ${ }^{84}$ The second case referred by the prosecutor was the 2016 Wang Chingyu's case. This case was another random killing in Taipei City that involved the death of a four-year-old girl. The victim was killed and decapitated in front of her mother. ${ }^{85}$ Cheng was sentenced to death and executed in $2016,{ }^{86}$ and Wang was sentenced to life imprisonment in $2017 .{ }^{87}$ These incidents shocked Taiwan, where violence and killings were rare.

Although the mock trial case did share some similarities with the two cases, in the case at hand, no one was killed and the victims suffered only comparatively minor injuries. Therefore, it seemed prosecutors mentioned these cases to provoke lay judges and to remind them that the society was not safe. Had there been a rule of evidence, the defence may have objected to the mentioning of these two cases because they may have caused undue bias on

\footnotetext{
81. Ibusuki, supra note 14, p. 48; Vandenbos (2015), p. 401; Wilson, supra note 25, p. 111.

82. Author's note on Changhua District Court Mock Trial 26-27 April 2018.

83. Ibid.

84. Hsu (2014).

85. Hsu \& Chin (2016).

86. Pan \& Chung (2016).

87. Pan (2017).
} 
the jury. The lack of rules of evidence indicates that legal professionals have yet to realize and accommodate the special needs of lay judges.

\subsection{Leniency toward Defendants?}

The comparison between lay judges and judges has always been an attractive topic for scholars. Most of the studies show that lay judges or juries usually produce more lenient results than trials presided over by professional judges alone. In the US, a classic study of more than 3,576 criminal trials conducted by Kalven and Zeizel found that juries and judges agreed in $78 \%$ of the cases. For the rest of the $22 \%$ of cases, when they disagreed, $19 \%$ would result in a conviction if decided by judges. ${ }^{88}$ In Korea, there was evidence indicating that, while judges in most cases followed the jury's recommended punishment, judges imposed harsher sentences when they disagreed with the jury. ${ }^{89}$ Similarly, in Argentina, a study showed that, in mixed tribunals of three professional judges and eight lay judges, lay judges agreed with professional judges in $79 \%$ of all cases. When this disagreement occurred, lay judges were more lenient than professional judges. ${ }^{90}$ Data collected from the pre-war Japanese jury also suggest that juries were more lenient than judges in determining both sentencing and guilt. ${ }^{91}$ The result for Japanese saiban-in trials was complicated. It was reported that, while the conviction rate did not change much, lay judges' participation did affect sentencing. For cases that involved sexual violence or bodily harm that resulted in death and murder, saiban-in trials delivered the harsher sentence. For other kinds of cases, however, saiban-in trials produced more lenient results. ${ }^{92}$

Although it is too early to determine whether lay judges in Taiwan will be more lenient or harsher, it may be interesting to report the observations from the four mock trials. As mentioned before, the mock trials used real case files, real judges, and real attorneys. The people acting as witnesses would read the dossier and the transcripts of the actual trial before the mock trial. Therefore, to some extent, the lay judges were exposed to the same information as judges who presided at the original trial. Among the four mock trials, two of the trials delivered virtually the same judgments as the original verdicts. The original verdict for the metro stabbing spree case was two counts of attempted murder, two counts of assault, and one count of theft. The defendant was sentenced to 12 years. The lay judge trial delivered the same guilty verdict and sentenced the defendant to 13 years. In the Changhua case, the autopsy report showed that the defendant stabbed so hard that the knife severed a section of the victim's spine. The original verdict found him guilty of murder and sentenced him to 14 years. The lay judges trial also found him guilty of murder and sentenced the defendant to 14 years and ten months. ${ }^{93}$

The other two cases in Chiayi and Taipei, however, deviated from the original verdict. In the Chiayi arson case, the original verdict sentenced the defendant to four years and six months, but the lay judge trial delivered a reduced sentence of two years. In the Taipei case,

88. Vidmar \& Hans, supra note 78, p. 148.

89. Park, supra note 16, p. 573.

90. Bergoglio (2016), p. 230.

91. Ambler (2007), p. 41.

92. Wei (2014), pp. 72-3.

93. Author's note on Changhua District Court Mock Trial 26-27 April 2018; author's note on Shilin District Court Mock Trial 8-9 February 2018. 
the defendant was convicted of attempted murder and sentenced to seven years. The lay judge trial reduced the charge to simple assault and sentenced him to two years and six months. $^{94}$

It is difficult to determine exactly why lay judges in the latter two cases produced more lenient results than the original verdicts. However, a possible explanation is that, compared to the seemingly cold-blooded defendants in Changhua and Shilin, the factual elements of the cases in Chiayi and Taipei provided more room for sympathy. The Chiayi case involved a person who was accused of attempting to set fire to his house after an argument with his mother. The defendant testified that he suffered from mental illness and did not know how the fire was started because he fell asleep after taking medicine for his condition. The fire was extinguished before it could cause damage to the house. Although the mother called the police when she discovered the fire, she testified that she forgave her son. ${ }^{95}$ The defendant in the Taipei case acted after learning that his wife mortgaged his house without consulting him and the victim suffered only minor injuries. The interview revealed that lay judges emphasized the relationship between the defendant and his wife. Evidence indicated that the victim abused the defendant in the relationship. They also suspected the wife might have set up the defendant because the wife's testimony seemed untrustworthy and "too perfect to be true." ${ }^{\prime 96}$ Finally, the identity of the victim may also impact the decision. During the victim's testimony, it was revealed that the victim was a marriage immigrant from China. Many people hold unfavourable views of Chinese who migrated to Taiwan through marriage, often stereotyping them as "gold diggers" or "prostitutes." "97 A couple of lay judges admitted in the interview that the identity of the victim had affected their judgment. ${ }^{98}$ Whether sympathy will play a larger role in lay judge trials than trials presided by professional judges alone requires further investigation. The observation of these two cases simply shows that judges and attorneys should seriously consider the sympathy factor of sympathy in future lay judge trials.

The apparently biased comment on marriage immigrants made by the lay judges also serves as a reminder to the designers of the system that stereotypes regarding racial, ethnicity, or gender will continue to haunt the lay judge system of Taiwan. Taiwan is a diverse society that has local aboriginal tribes and a substantial number of immigrants from China and Southeast Asia who came to Taiwan because of marriage or work. It is foreseeable that Taiwan's courts will face problems similar to Pena-Rodriguez v. Colorado, ${ }^{99}$ a recent US Supreme Court case regarding the effects of jurors making racially biased comments during deliberation.

\section{DISCUSSION}

Many of the problems described in this article resonate with existing literature. First of all, although Taiwan followed the Japanese model of selecting lay judges on a case-by-case basis

94. Author's note on Taipei District Court Mock Trial 30-31 January 2018; author's note on Chiayi District Court Mock Trial 1-2 February 2018.

95. Author's note on Chiayi District Court Mock Trial 1-2 February 2018.

96. Author's note on Taipei District Court Mock Trial 30-31 January 2018

97. Pan (2015), p. 143.

98. Author's note on Taipei District Court Mock Trial 30-31 January 2018.

99. Pena-Rodriguez v. Colorado, 137 Supreme Court Case 855, 2017. 
instead of the tenured German model, professional judges' domination that was observed in European mixed tribunals was also found in both guilt and sentencing phases of the mock trials. That is, although the case-by-case model may help to prevent improper influence of the judicial culture and the professionalization of lay judges, the results of the mock trials still establish that the concern for judicial domination remains. Furthermore, because sentencing decisions are more complicated and involve more technicalities than guilt decisions, mock trial lay judges encountered significantly more difficulties during the sentencing phase. Eventually, this problem triggered further intervention from professional judges and undermined the sense of accomplishment of lay judges. Second, I observed the important concern of the Japanese saiban-in system - the problem of the comprehensibility of law-in these mock trials. The lay judges clearly had difficulties in understanding some of the legal concepts and terminologies. The mock trials also revealed that prosecutors and lawyers have yet to adequately accommodate the needs of lay participants by adopting a narrative-focused method of presentation and speaking eloquently in front of the court without the overreliance on PowerPoint slides. These issues were asked and answered when Japan was preparing to implement the saiban-in system. Their solution was to hold a large-scale educational programme for both laypersons and legal professionals. Taiwan has yet to implement educational programmes with the same scale.

Although the 2018 proposal mostly followed the Japanese model, the two countries share many common problems. Still, new problems occurred when the Judicial Yuan tried to transplant the Japanese model to Taiwan. It is foreseeable that these issues will become the centre of debate in the years to come. Understanding Taiwan's experiences may provide new perspectives in designing a new lay participation system, especially for countries that are transforming away from the inquisitorial tradition.

One of the most hotly debated issues in Taiwan focuses on the discovery procedure. The reason is straightforward: the current practice of discovery in Taiwan is essentially an openfile procedure, meaning that the defence may copy and review the whole dossier right after indictment. Disclosing evidence in stages would significantly make it more difficult for the defence to develop its case theory. Moreover, the three-stage discovery system allows prosecutors to withhold certain pieces of evidence if the prosecutor deems the evidence unimportant or irrelevant. However, in practice, it is not uncommon for the two parties to have an entirely different interpretation of the same piece of evidence. What is considered significant by the defence may be regarded as unimportant by the prosecutor. Different interpretations of evidence are derived from different perspectives and contexts. Allowing the prosecutor to withhold evidence seems to overlook the inherent risk of different interpretations. If the prosecutor denies the defence's motion to disclose evidence, the defence may take the issue to the presiding judge. Then, the defence faces another problem: how to persuade the presiding judge that a certain piece of evidence is important without knowing the exact content of that evidence. Based on these problems, the defence attorneys in Taiwan oppose adopting the new discovery procedure as they believe the new Bill will significantly increase the impediments preventing the defendant from receiving information.

The adoption of the new discovery procedure reflects the designers' failure to consider of Taiwan's status quo and the differences between Taiwan and Japan. When Japan adopted their new discovery system in 2016, many considered it a step forward for the defence. Before 2016, the defence had no way to know the contents of the prosecutor's file. In many 
instances, the defence can only guess what the dossier should contain. ${ }^{100}$ The 2016 revision requires the prosecutor to provide a list of evidence to the defence during discovery. Although many lawyers were not entirely satisfied with the new law because the list only contains the title of each piece of evidence but not the content, it was still considered an advancement in law. Unlike Japan, Taiwan does not have a so-called previous discovery procedure. Dossiers are sent to courts and open for review after indictment. The prosecutor does not reserve any evidence, and the defence does not have to negotiate for evidence. Taiwan's open-file discovery procedure is transparent and allows the defence to review all the evidence to develop the best theory available. Adopting the Japanese three-stage discovery rule would neglect that Taiwan's current system provides more protection to the defendant and does not necessarily require reform. ${ }^{101}$

Another problem of transplanting Japan's system is requiring lay judges to make sentencing decisions. The purpose of Taiwan adopting a lay participation system is to win back the people's trust toward the judiciary. The designers, therefore, thought it would be appropriate to follow Japan and the tradition of mixed tribunals to allow lay participants to make sentencing decisions. However, based on direct observation and interview, this study shows many lay judges are frustrated by the technicalities of the sentencing phase, and many expressed that sentencing decisions should not be made by lay judges. When a sense of achievement is lacking, it deteriorates the overall satisfaction with the new system and undermines the very purpose of adopting a lay participation system.

The discussion on the saiban-in system did not put much emphasis on this problem. When the JSRC was designing the lay participation system of Japan, they aimed to allow laypeople to "participate autonomously and meaningfully in trial decisions while sharing responsibilities with judges." 102 It was clear then that the new system would allow laypersons to determine not only guilt, but also sentencing. The JSRC emphasized that the "significance (of saiban-in trial) applies not only to fact-finding and decisions on guilt, but in the same way to decisions on sentencing, as to which the public takes a strong interest." ${ }^{\text {"103 }}$ The biggest concern for the designers of the system was that laypersons may undermine criminal procedure's goal of searching for the truth and maintaining consistency for sentencing. Therefore, they mandated judges to provide laypersons with sentencing decisions of previous, similar cases for reference. ${ }^{104}$

However, the problem of frustration and the lack of a sense of achievement regarding sentencing observed in Taiwan was not about the fairness of the final result, but the subjective perception, experience, and satisfaction of the lay judges. The dissatisfaction observed in the mock trials was an unexpected problem of the lay judge system. This problem is particularly crucial for Taiwan because, compared to Japan, the Taiwan judiciary is facing a much more unfriendly public opinion against the judiciary. The result of recent

100. Follaw (2018).

101. Another example of Taiwanese law provides more protection to the defendant than Japanese law is on the issue of videotaping interrogations. Japan has just begun to experiment on videotaping interrogations and using the video record as evidence in a trial. Miyazawa \& Hirayama (2017), pp. 164-5. On the other hand, the Taiwan Code of Criminal Procedure Art. 100-1 has mandated that all interrogations of the defendant must be videotaped since 1997. It is now very common to use videotaped interrogation as evidence in a trial.

102. Senger (2011), p. 747.

103. Weber (2009), p. 156.

104. Ibid., p. 157. 
surveys has been unfavourable to the judiciary. A 2015 survey conducted by the National Chung Cheng University shows an $84.6 \%$ distrust rate for judges. Another survey conducted by the Judicial Yuan in 2016 shows $48.5 \%$ of the people distrust judges. Comparing a 2016 Japanese survey that shows a $75.6 \%$ trust rate toward judges, the Taiwan judiciary is clearly facing a more severe crisis. ${ }^{105}$ Therefore, from what we learned from the mock trials, to prevent the lay judge system from further undermining the public's perception of the judiciary, it seems imperative to either provide more guidance to lay judges on sentencing and simplify the procedure or to prevent lay judges from making sentencing decisions altogether.

A third problem is the lack of evidence rules. The Japanese system does not have a complex system of evidence rules but does authorize the presiding judge to control or limit the questions raised to witnesses and allow both parties to object to improper questioning. ${ }^{106}$ The new Bill adopted the Japanese model and gave the presiding judge a general power to limit improper questioning. However, this study shows that a generalized provision simply does not meet the demands of the complex court activity in Taiwan. It was clear that not only the two parties, but also the presiding judge needed more sophisticated rules of evidence to argue or to make decisions.

Rules of evidence are important because they allow legal professionals to control the information presented to lay judges. Rules provide an opportunity for legal professionals to exclude certain pieces of evidence that may taint lay judges who may become biased, misled, or confused. Some may argue that mixed tribunals do not need rules of evidence because professional judges can provide guidance to lay judges to prevent them from being tainted by evidence. However, from what we learned in the literature and these mock trials, the most important mission for a mixed-tribunal professional judge is arguably not to reveal their opinions too early and dominate the deliberation process. Therefore, asking professional judges to comment on evidence outright may not be the best approach to achieve such a goal. The adoption of evidentiary rules would create a controlled and friendly environment for lay judges to make decisions and reduce the possibility of making mistakes.

It is not surprising that Japan did not adopt more complex rules of evidence. On one hand, Japan is still highly influenced by the civil-law tradition that focuses on the truth-seeking function of criminal procedure and entrusts the trier of fact with the power to properly weigh the evidence and to defy the risks of bias. ${ }^{107}$ On the other hand, there is also a cultural reason. It was reported that the adversary process and the trial were "highly circumscribed" in Japan. The trial was once described as a "formal ceremony." 108 The intensity between the adversarial parties was low because cases were usually dominated by prosecutors, and the few attorneys who were willing to take criminal cases usually did not contest fiercely against prosecutors. ${ }^{109}$ Not to mention that Japan's criminal conviction rate can rise as high as $99.8 \%{ }^{110}$ In reality, there is not much hope for the defence after indictment. With this background in mind, there is no point in Japan adopting a set of rules to motivate the parties to argue vigorously about the admissibility of evidence in court.

\footnotetext{
105. Wang (2017), p. 4.

106. Senger, supra note 102, p. 746.

107. Weber, supra note 103, p. 144.

108. Foote (1992), p. 339.

109. Ibid., p. 338.

110. Wilson (2010), p. 506.
} 
The defence attorneys in Taiwan, however, are more active in the adversarial process. According to the official statistics announced by the Ministry of Justice of Taiwan, although the overall conviction rate can reach around $96 \%$, for certain crimes, the conviction rates are significantly lower, including bribery $(66.63 \%)$, breach of trust $(83.91 \%)$, crimes against sexual autonomy $(86.52 \%)$, extortion and kidnapping for ransom $(84.88 \%)$, offences against abandonment (89.08), and offence of forging instruments $(89.55 \%) .{ }^{111}$ From what was observed in these mock trials, young lawyers who volunteered to serve as defence attorneys typically saw the new system as a new opportunity for business. Recently, a new Criminal Defence Attorney Association was formed by a few elite lawyers. The first class they offer is cross-examination, which is a key part of a lay judge trial. Therefore, the problem of Taiwan's lay judge trial is not that defence attorneys are unwilling to take criminal cases or not motivated to argue vigorously against the prosecutor. The problem is that the law does not provide a basis for argument. In these mock trials, there were a few instances when lawyers argued about the potential bias effect of a piece of evidence; the court was forced to make a ruling on such an argument. However, because there was no law regulating those kinds of evidentiary disputes, the decision of the court appeared arbitrary and unpredictable. The lack of evidentiary rules, once again, is an example for neglecting the differences between Taiwan and Japan.

\section{CONCLUSION}

This article describes some of the important issues observed from four of the lay judge mock trials held between January and April 2018 in Taiwan. Many of the issues are deeply rooted in the traditions, habits, and cultures of Taiwan's criminal procedure and judicial system. Although the Judicial Yuan's effort to reconnect with the people is worthy of praise, the designers should also realize that the gap between laypersons and legal professionals cannot be bridged overnight. The legal process should be treated as an ecological system. A successful American jury trial, for example, requires a fair judge, two brilliant attorneys who are both diligent and eloquent, and a group of laypersons who understand the meaning and importance of the trial procedure. It even requires movies and television shows that help to cultivate citizens who are familiar with the judicial process. Adding an element to an existing judicial system should be conducted with caution, as it might change the overall ecological environment.

This article proposes four possible solutions to the problems observed in these four mock trials. First, a training session should be provided to lay judges before trial, at least until a couple of years after the law passes. Learned from the mock trials, people in Taiwan are generally strangers to courts and the criminal procedure. They had significant difficulties in understanding the legal language and the procedures. This problem could impede lay judges from following the trial, participating in the procedures meaningfully, and becoming dominated by professional judges. Second, the Judicial Yuan should abolish the three-stage discovery rule. The Japanese discovery rule does not fit into the status quo of Taiwan's criminal procedure. The existing open-file discovery procedure of Taiwan allows the defence to

111. Ministry of Justice Taiwan (2016), p. 2. 
review the whole dossier and produce the best defence available, lowers the possibility of wrongful convictions, and is arguably better than the proposed discovery rule.

Third, unless the Judicial Yuan creates a system that can successfully guide lay judges through the technicalities of sentencing, their participation in the sentencing phase should be limited. For lay judges who participated in the mock trials, sentence deliberation was the main source of their frustration. They were asked to make decisions without sufficient reference or guidance. Courts should ask lay judges to do what lay judges excel atsupplementing professional judges with lay judges' common sense. A possible solution is to ask lay judges to simply choose whether they prefer harsh, moderate, or lenient sentencing after hearing all evidence or to prevent lay judges from participating in sentencing deliberations altogether. ${ }^{112}$

Fourth, the Judicial Yuan and the Ministry of Justice should work with the bar association to provide training sessions to empower trial lawyers. A successful adversarial trial requires defence attorneys to be somewhat equally knowledgeable and resourceful as prosecutors. The training sessions should include the skills of cross-examination, oral argument, and the appropriate way of using technology in court. Furthermore, education and training should extend to the training academies for newly admitted judicial officers and lawyers. To equip the next generation of lawyers with the skills and knowledge necessary to litigate lay judge trials, law schools should provide trial practice courses.

Finally, the judiciary should create an evidentiary rule that considers prevents lay judges from becoming confused or misled. Courts should provide an opportunity for professional judges and attorneys to debate on risks of bias and confusion before evidence is presented to lay judges. If conducted properly, evidence issues can be settled before trial or out of sight of lay judges during a trial, thus reducing the risks of improper influence. Even more importantly, if courts can resolve evidentiary issues among legal professionals, professional judges would not have to risk the possibility of influencing lay judges by out-rightly revealing their opinions on the evidence during deliberation. Another evidentiary rule that should be considered is the rule governing expert witnesses. The current laws in Taiwan do not provide clear guidance to judges concerning the admissibility of expert witnesses. From what was learned in the mock trials, expert witnesses can easily influence lay judges. This is particularly disturbing because the defence usually does not have experts to summon, since most forensic science experts are related to law enforcement.

The lay judge system should serve not only as a political institution, but also as a judicial institution. The problems observed in the mock trials indicated that, while the lay judge system in Taiwan may give lay judges the same power as professional judges, the system has not yet fully accommodated the needs of the lay judges to ensure the production of accurate results.

\section{REFERENCES}

Ambler, Leah (2007) "The People Decide: The Effect of the Introduction of the Quasi-Jury System (Saiban-In Seido) on the Death Penalty in Japan." 6 Northwestern Journal of International Human Rights 1-72.

112. Lay judges in Venezuela's mixed courts only decide questions of fact. Thaman (2003), p. 109. 
Bergoglio, Maria Ines (2016) "Citizen Views on Punishment: The Difference between Talking and Deciding." 6 Oñati Socio-legal Series 216-34.

Bill of Lay Judges (2018) http://social.judicial.gov.tw/LayJudge/Promoted/Preliminarydraftexplanation (accessed 5 January 2019).

Devine, Dennis J. (2012) Jury Decision Making: The State of the Science, New York: New York University Press.

Follaw (2018) "International Conference on Discovery: Are We Going Backward?" https://www. follaw.tw/f-comment/f05/15829/ (accessed 1 May 2018).

Foote, Daniel H. (1992) "The Benevolent Paternalism of Japanese Criminal Justice." 80 California Law Review 317-90.

Fukurai, Hiroshi (2007) “The Rebirth of Japan's Petit Quasi-Jury and Grand Jury Systems: A CrossNational Analysis of Legal Consciousness and the Lay Participatory Experience in Japan and the U. S." 40 Cornell International Law Journal 315-54.

Fukurai, Hiroshi (2013) “A Step in the Right Direction for Japan's Judicial Reform: Impact of the Justice System Reform Council (JSRC) Recommendations on Criminal Justice and Citizen Participation in Criminal, Civil, and Administrative Litigation." 36 Hastings International \& Comparative Law Review 517-67.

Fukurai, Hiroshi, Kay-Wah Chan, \& Setsuo Miyazawa (2010) "The Resurgence of Lay Adjudicatory System in East Asia." 12 Asian-Pacific Law \& Policy Journal i-xi.

Hans, Valerie P. (2008) "Jury Systems Around the World." 4 Annual Review of Law \& Social Science 275-96.

Hans, Valerie P. (2017) “Trial by Jury: Story of Legal Transplant.” 51 Law \& Society Review 471-99.

Hendler, Edmundo (2008) "Lay Participation in Argentina: Old History, Recent Experience." 15 Southwestern Journal of Law and Trade in the Americas 1-29.

Hsu, Sheng-lun, \& Jonathan Chin (2016) "Man Decapitates Girl in Front of Mother," Taipei Times, 29 March.

Hsu, Stacy (2014) "MRT Attacker Kills 4 People, Injures 22," Taipei Times, 22 May.

Ibusuki, Makoto (2010) “'Quo Vadis': First Year Inspection to Japanese Mixed Jury Trial.” 12 Asian Pacific Law \& Policy Journal 24-58.

Ivkonic, Sanja K. (2007) "Exploring Lay Participation in Legal Decision-Making: Lessons from Mixed Tribunals." 40 Cornell International Law Journal 429-53.

Jrf (1998) "We Need Prosecutors to Participate in Courtroom Activities," https://www.jrf.org.tw/ newjrf/index_new2014.asp?id=1988 (accessed 1 May 2018).

Judicial Yuan (2011) "A Proposal on the Trial Observers-Q\&A Advanced Version." 57 The Military Law Journal 201-20.

Judiciary (2018) "Magistrates," https://www.judiciary.uk/about-the-judiciary /who-are-the-judiciary/ judicial-roles/magistrates/ (accessed 1 November 2018).

Kwon, Soonmin (2016) "Toward Democracy in Criminal Procedure: The Significance and Limitation of Citizen Participation in Criminal Trials in an Attempt to Accomplish Democracy in Criminal Justice in Korea." 37 Northern Illinois University Law Review 101-24.

Landsman, Stephan, \& Jing Zhang (2008) "A Tale of Two Juries: Lay Participation Comes to Japanese and Chinese Courts." 25 UCLA Pacific Basin Law Journal 179-227.

Lee, Jae-Hyup (2009) "Getting Citizens Involved: Civil Participation in Judicial Decision-Making in Korea." 4 East Asia Law Review 177-207.

Lee, Jae-Hyup, \& Jisuk Woo (2016) "Judge-Jury Interaction in Deliberation: Enhancement or Obstruction of Independent Jury Decision-Making?" 6 Oñati Socio-legal Series 179-96.

Levett, Lora M., \& Dennis Devine (2017) "Integrating Individual and Group Models of Juror Decision Making," in M. B. Kovera, ed., The Psychology of Juries, Washington, DC: American Psychological Association, 11-36.

Levin, Mark, \& Virginia Tice (2009) “Japan's New Citizen Judges: How Secrecy Imperils Judicial Reform." 19 Asia-Pacific Journal 91-9. 
Ministry of Justice of Taiwan (2016) "Analysis on the indictment Rates and Conviction Rates of Major Offenses," http://www.rjsd.moj.gov.tw/rjsdweb/common/WebListFile.ashx?list_id=1417 (accessed 8 August 2018).

Miyazawa, Setsuo, \& Mari Hirayama (2017) "Introduction of Videotaping of Interrogations and the Lessons of the Imaichi Case: A Case of Conventional Criminal Justice Policy-Making in Japan.” 27 Washington International Law Journal 149-76.

Okawara, Mami Hiraike (2012) "Lay Understanding of Legal Terminology in the Era of the Japanese Lay Judge System." 12 Comparative Legilinguistics 19-47.

Pan, Wang (2015) Love and Marriage in Globalizing China, New York: Routledge.

Pan, Jason (2017) "Killer of 'Little Light Bulb' Gets Life Prison Term,” Taipei Times, 13 May.

Pan, Jason, \& Jake Chung (2016) "MRT Murderer Executed with Appeal Unheard," Taipei Times, 11 May.

Park, Ryan Y. (2010) "The Globalizing Jury Trial: Lessons and Insights from Korea." 58 American Journal of Comparative Law 525-82.

Pennington, Nancy, \& Reid Hastie (1993) "The Story Model for Juror Decision-Making," in R. Hastie, ed., Inside the Juror: The Psychology of Juror Decision Making, Cambridge: Cambridge University Press, 192-222.

Senger, Daniel (2011) "The Japanese Quasi-Jury and the American Jury: A Comparative Assessment of Juror Questioning and Sentencing Procedures and Cultural Elements in Lay Judicial Participation." 2011 University of Illinois Law Review 741-74.

Sun, Jian Zhi (2013) Judicial Research Report: A Study on Lay Participation, Volume 30:2, Taipei: Judicial Yuan.

Taiwantoday (2012) “The People's Court," https://taiwantoday.tw/news.php?unit=4,29,29,31,45\&post $=7944$ (accessed 1 May 2018).

Thaman, Stephan C. (2003) "Japan's New System of Mixed Courts: Some Suggestions Regarding Their Future Form and Procedures." 2002 Saint Louis-Warsaw Transatlantic Law Journal 89-117.

Vandenbos, Caleb Jon F. (2015) "Patching Old Wineskins: Heightened Deference Towards Saiban-in Findings of Fact on Koso Appeals is Not Enough.” 24 Washington International Law Journal 391418.

Vidmar, Neil, \& Valerie P. Hans (2007) American Juries: The Verdict, New York: Prometheus Books.

Wang, Xiao-Dan (2017) "Legal Consciousness and Trust of the Judiciary." 21 Taiwan Prosecutor Review 13-23.

Weber, Ingram (2009) "The New Japanese Jury System: Empowering the Public, Preserving Continental Justice." 4 East Asia Law Review 125-76.

Wei, Pei-Xuan (2014) "Japanese Saiban-in Seido: Introduction and Review after Three Years of Practice." 102 Judicial Reform Magazine 68-75.

Wilson, Matthew J. (2010) “Japan's New Criminal Jury Trial System: In Need of More Transparency, More Access, and More Time." 33 Fordham International Law Journal 487-571.

Wilson, Matthew J. (2017a) "Assessing the Direct and Indirect Impact of Citizen Participation in Serious Criminal Trials in Japan." 27 Washington International Law Journal 75-118.

Wilson, Matthew J. (2017b) "The Dawn of Criminal Jury Trials in Japan: Success on the Horizon?" 24 Wisconsin International Law Journal 835-70.

You, Qing-Xin, \& Zhen-Hua Yu (2018) "Judicial Yuan's Polls on Lay Participation," http://social. judicial.gov.tw/LayJudgeAttach/02C0/\%E5\%8F\%B8\%E6\%B3\%95\%E9\%99\%A2\%E5\%9C\%8B \%Е6\%B0\%91\%Е5\%8F\%83\%Е8\%88\%87\%Е5\%88\%91\%Е4\%BA\%8B\%Е5\%AF\%A9\%Е5\% 88\%A4\%E5\%A0\%B1\%E5\%91\%8A\%E6\%9B\%B8(\%E5\%AE\%9A\%E7\%A8\%BF).pdf (accessed 13 May 2018).

Zhang, Yong-Hong (2018) “The Virtuous Cycle of the Judicial System Starts from Here,” Apple Daily, 3 March.

Zheng, Wen Long (2013) "The Jury System—a System that Allows the People to Make Decisions." Legislature Hearing on the Lay Participation System, 8th Congress of Taiwan. 